\title{
PEMANFAATAN BANGUN-BANGUN (Coleus amboinicus) DI GAWANGAN TBM KARET UNTUK PENGENDALIAN JAMUR AKAR PUTIH DAN KESUBURAN TANAH
}

\author{
Utilization of Bangun-Bangun (Coleus amboinicus) on Interrow of Immature Rubber Plant as manage \\ of White Root Diseases and Soil Fertility
}

Mochlisin Andriyanto, Cici Indriani Dalimunthe dan Yan Riska Venata Sembiring

Balai Penelitian Sungei Putih, PO. Box. 1415 Medan 2000

Email: mochlisin.andriyanto.agh45@gmail.com

Diterima 16 Juni 2017 / Direvisi 4 Oktober 2017 / Disetujui 9 Oktober 2017

\begin{abstract}
Abstrak
Tanaman bangun-bangun (Coleus amboinicus) merupakan tanaman indigenous asal Sumatera Utara yang belum banyak dibudidayakan secara kultur teknis. Tujuan penelitian ini ialah untuk memanfaatkan areal gawangan tanaman karet belum menghasilkan (TBM) dengan menanam tanaman bangunbangun. Penelitian ini dilakukan di Kebun Percobaan Balai Penelitian Sungei Putih pada bulan Maret-Agustus 2015. Hasil penelitian menunjukkan bahwa tanaman bangunbangun dapat tumbuh baik di gawangan tanaman karet pada TBM-3 karet. Tanaman ini berpotensi sebagai anti jamur untuk mengendalikan penyakit jamur akar putih (JAP). Tanaman bangun-bangun dapat menghambat serangan penyakit JAP dengan cara menanam langsung di lapangan sebesar $23,53 \%$. Kandungan protein pada tanaman ini juga dapat meningkatkan kesuburan tanah, khususnya dalam meningkatkan ketersedian $\mathrm{N}$ dalam tanah.
\end{abstract}

Kata kunci : karet, TBM, bangun-bangun, JAP, kesuburan tanah

\section{Abstract}

Bangun-bangun (Coleus amboinicus) is an indigenous plant in North Sumatera that has not been cultivated. The objectives of research were to used interrow of immature rubber plant by bangunbangun cultivation. This research was conducted at
Sungei Putih Experimental Garden in MarchAugust 2015. The result showed that bangunbangung growth up in interrow of immature rubber plant. This plant has potential as an antifunctional agent to control white root disease (WRD). The protein content of this plant could be increased bangun-bangun was also increasing of soil fertility, especially the availability of nitrogen in the soil.

Keywords : Hevea brasiliensis, immature, Bangun-bangun, WRD, Soil Fertility

\section{Pendahuluan}

Salah satu kendala yang cukup siginifikan mempengaruhi produktivitas tanaman karet adalah serangan penyakit jamur akar putih (JAP). Penyakit JAP disebabkan oleh jamur Rigidiporus microporus yang melekat erat pada permukaan akar tanaman. Kerugian yang ditimbulkan penyakit ini mencapai 300 miliar sampai 1,8 triliun rupiah per tahun dengan tingkat keparahan 3\% di perkebunan besar dan $5 \%$ perkebunan rakyat (Rahayu et al., 2006; Situmorang et al., 2007). Serangan JAP utamanya terdapat pada kebun karet muda dan diketahui gejalanya di lapangan setelah berumur satu tahun (Basuki \& Sinulingga, 1996). Sifat patogen Rigidiporus microporus sangat bervariasi. Tingkat ketahanan tanaman karet sebagai inang bervariasi sehingga respon setiap tanaman juga berbeda-beda (Setyawan \& Admojo, 2009). Gejala serangan JAP terlihat jelas pada perubahan warna daun 
menjadi kusam, menguning dan rontok bila terdapat di areal akar lateral, namun bila terdapat pada akar tunggang maka tanaman akan mudah tumbang akibat pembusukan (Fairuzah et al., 2014).

Pemanfaatan gawangan karet dengan penanaman tanaman antagonis dapat digunakan sebagai alternatif untuk menghambat perkembangan jamur akar putih (JAP) dan meningkatkan kesuburan tanah. Perkebunan karet memiliki potensi luas lahan yang cukup besar digunakan untuk penanaman komoditas lain terutama pada saat tanaman belum menghasilkan (TBM). Lahan yang dapat digunakan di TBM karet adalah gawangan dan umumnya dapat digunakan selama \pm 5 tahun. Bila lahan gawangan karet tidak dioptimalkan pemanfaatannya, maka banyak energi matahari yang tidak dapat dipanen atau dimanfaatkan oleh gulma liar (Siagian, 2005).

Tanaman bangun-bangun memiliki potensi sebagai tanaman antagonis terutama dalam hal pengendalian penyakit dan kesuburan tanah sehingga diharapkan dapat meningkatkan produktivitas tanaman karet. Bangun-bangun (Coleus amboinicus) merupakan tanaman indigenous yang berasal dari Sumatera Utara yang mampu beradaptasi pada tempat ternaungi hingga $60 \%$ dengan drainase yang baik (Aziz, 2013; Damanik et al., 2006). Umumnya tanaman ini banyak digunakan dalam dunia pengobatan sebab secara botani daunnya memiliki aroma yang kuat, tanamannya succulent dan rasanya cukup pedas (Saraswathy et al., 2011).Tanaman ini mengandung senyawa fenolik yang berpotensi sebagai antijamur dan dapat digunakan sebagai fungisida alami (Ansari et al., 2013). Hasil penelitian Dalimunthe et al. (2016) menunjukkan bahwa ekstrak akar tanaman bangun-bangun dapat menghambat pertumbuhan jamur akar putih sebesar $98,46 \%$ di Laboratorium. Senyawa yang terkandung dalam akar tanaman bangun-bangun bersifat polar dan semi polar yaitu senyawa flavonoid, glikosida dan saponin.
Beberapa hasil penelitian tersebut menunjukkan tanaman bangun-bangun berpotensi sebagai tanaman antagonis terhadap JAP. Seperti halnya 4 jenis tumbuhan antagonis yaitu kunyit, laos, lidah mertua, dan cocor bebek yang dapat mengurangi sumber infeksi jamur akar putih pada tunggul karet (Situmorang et al., 2006). Eksudat antibiotik pada daerah perakaran tanaman antagonis mengakibatkan perubahan sifat bio-kimia-fisik tanah yang dapat menghambat perkembangan penyakit JAP (Situmorang et al., 2006). Perubahan sifat bio-kimia-fisik tanah disebabkan tanaman bangun bangun bersifat antifungi. Tanaman bangun-bangun mengandung $74 \%$ carvacol dan p-cymene yang tergolong dalam minyak atsiri dan berfungsi untuk melawan antibakteri dan antijamur (Valera et al., 2003). Senyawa lain yang terkandung dalam bangun-bangun adalah saponin dan flavonoid (Sajimin et al., 2011). Flavonoid memiliki sifat antioksidan yang dapat mengubah radikal bebas ke bentuk stabil dengan nilai IC 50 (Mualim, 2012). Saponin yang bersifat antimikroba pada tanaman bangun-bangun dapat ditingkatkan bila interval panen pucuk lebih panjang (Ekawati, 2013).

Tanaman bangun-bangun umumnya masih didapatkan dan dipanen dari alam, serta belum banyak dibudidayakan secara massal. Oleh karena itu, tulisan ini membahas tentang budidaya tanaman bangun-bangun pada lahan gawangan TBM karet dan manfaatnya terhadap penyakit JAP dan kesuburan tanah.

\section{Bahan dan Metode}

Penelitian ini dilakukan pada bulan Maret Agustus 2015 di Kebun Percobaan Balai Penelitian Sungei Putih pada gawangan karet belum menghasilkan berumur tiga tahun dengan tiga gawangan (TBM 3) klon PB 260. Luas areal yang digunakan untuk menanam bangun-bangun adalah $5 \times 20 \mathrm{~m}$ per gawangan. Bahan tanam bangun-bangun diperoleh dari stek pucuk setinggi $\pm 5 \mathrm{~cm}$ yang ditanam di 
media polibeg selama sebulan (Gambar 1). Sebelum dilakukan pengolahan tanah dilakukan penyemprotan gulma menggunakan herbisida. Satu minggu sebelum penanaman tanah di areal gawangan karet dicangkul dengan kedalaman 0-20 cm. Penanaman bangun-bangun menggunakan jarak $1 \mathrm{~m}$ dari tanaman utama karet dan jarak tanam bangun-bangun $40 \mathrm{~cm} \quad$ x $40 \mathrm{~cm}$. Pemeliharaan tanaman dilakukan sesuai dengan norma yang dianjurkan.

Adapun beberapa variabel yang diamati dalam penelitian ini yaitu :

a. Tanaman bangun-bangun

Adapun variabel yang diamati, yaitu tinggi tanaman, jumlah cabang, jumlah daun, lebar tajuk, berat basah dan berat kering tanaman bangun-bangun. Bobot kering diperoleh dari proses pengeringan setelah masa panen. Bobot basah diperoleh dari bobot hasil panen. Analisa protein dengan menggunakan metode Kjeldahl juga dilakukan untuk melihat kandungan protein yang terdapat pada daun dalam kaitannya dengan kondisi agronomi tanaman. Tanaman yang diukur sebanyak sebanyak 20 tanaman contoh setiap gawangan. Pemeliharaan tanaman meliputi penyiraman dan penyiangan gulma sampai dengan 12 MST. Penyiraman dilakukan setiap pagi hari bila tidak ada hujan.

b. Tanaman Karet

Intensitas serangan jamur akar putih/JAP (\%)

Pengamatan intensitas serangan JAP dilakukan sebelum penanaman bangunbangun. Setelah penanaman, pengamatan dilakukan intens dengan interval satu bulan sekali dengan cara membuka tanah di sekitar leher akar tanaman karet untuk mengetahui kategori nilai serangan.

Nilai kategori serangan diperoleh dengan menghitung jumlah kategori serangan sebagai berikut (Fairuzah et al., 2014):

Skala $0=$ akar tanaman terbebas dari serangan $R$. microporus

Skala 1 = akar tanaman ditumbuhi miselium $R$. microporus tetapi terbatas pada permukaan kulit

Skala $2=$ miselium telah melekat kuat pada kulit atau diperkirakan miselium telah masuk ke kayu

Skala 3 = bagian kulit dan kayu telah membusuk

Skala $4=$ tanaman mati
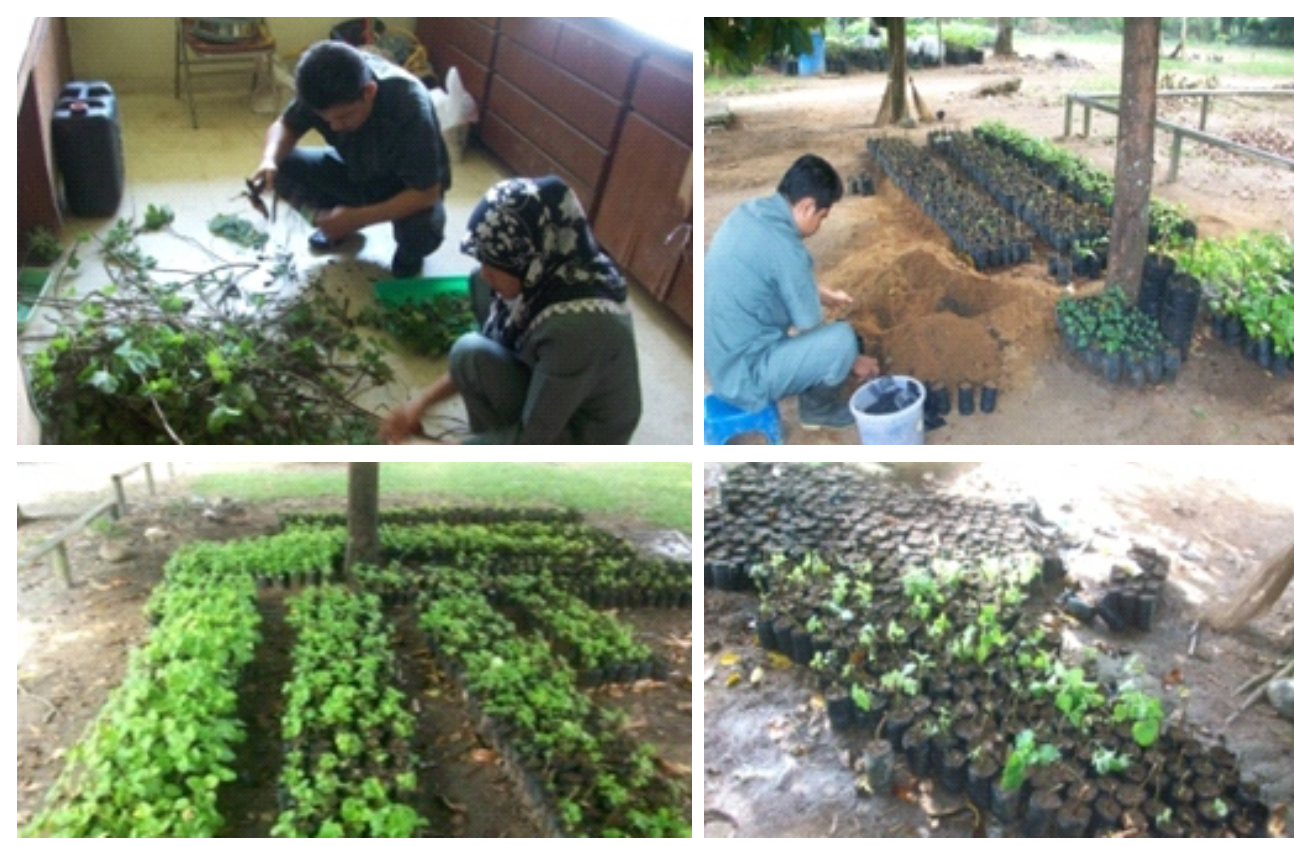

Gambar 1. Perbanyakan tanaman bangun-bangun di polibeg. 
Setelah mengetahui nilai kategori serangan, kemudian ditentukan intensitas serangan $R$. microporus dengan menggunakan rumus sebagai berikut:

$$
I=\frac{(\mathrm{n} \times \mathrm{v})}{(\mathrm{z} \times \mathrm{N})} \times 100 \%
$$

Keterangan:

I = intensitas serangan

$\mathrm{n}=$ jumlah akar tanaman sakit dari setiap kategori serangan

$\mathrm{v}=$ nilai skala dari setiap kategori serangan

$\mathrm{Z}=$ nilai skala dari kategori serangan tertinggi (4)

$\mathrm{N}=$ jumlah tanaman yang diamati

a. Analisis Hara Tanah

Analisis hara meliputi unsur hara nitrogen $(\mathrm{N})$, fosfor $(\mathrm{P})$, kalium $(\mathrm{K})$, dan magnesium (Mg). Analisis dilakukan sebelum dan sesudah penanaman bangun-bangun.

b. Analisis Protein

Analisis protein yang digunakan untunk tanaman bangun-bangun menggunakan metode Kjeldahl.

\section{Hasil dan Pembahasan}

\section{Pertumbuhan Tanaman Bangun-bangun di Gawangan Karet}

Kondisi tanaman bangun-bangun di gawangan karet menunjukkan pertumbuhan yang normal dan dapat dilihat pada Gambar 2 . Pertumbuhan tanaman bangun-bangun menunjukkan pola sigmoid dengan rataan tinggi tanaman mencapai $36,18 \mathrm{~cm}$ pada pengamatan 12 MST (Gambar 3). Rata rata pertambahan tinggi tanaman setiap minggu berkisar 1,75 cm. Banyak faktor yang mempengaruhi pertumbuhan tanaman bangun-bangun diantaranya faktor intensitas cahaya matahari yang masuk ke gawangan karet. Hasil penelitian menunjukkan bahwa jumlah intensitas cahaya yang masuk berkisar antara 498,27 - 592,6 lux. Intensitas cahaya yang masuk relatif sedikit karena adanya naungan dari tanaman karet. Hal ini sesuai dengan kondisi tanaman bangun-bangun menyukai tempat yang ternaungi, bila ditanam pada lahan terkena langsung matahari maka

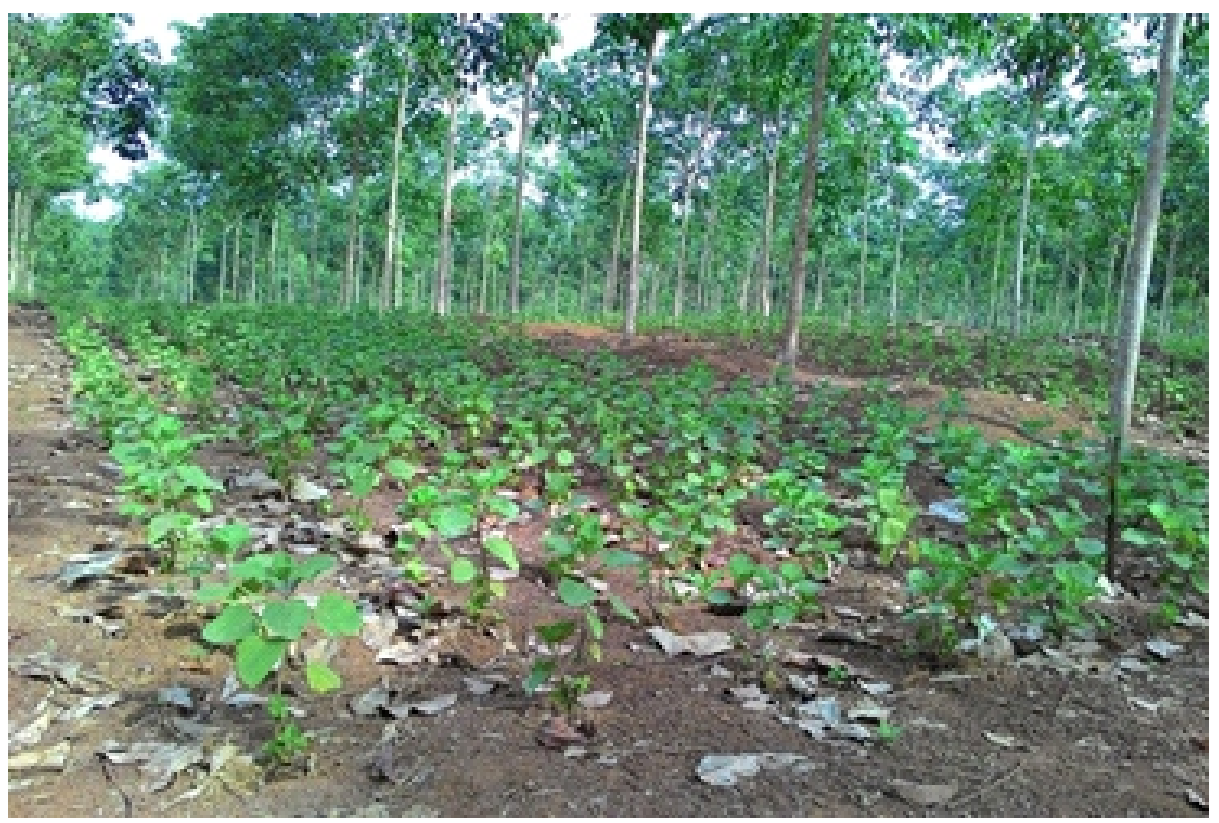

Gambar 2. Kondisi tanaman bangun-bangun pada gawangan TBM klon PB 260 


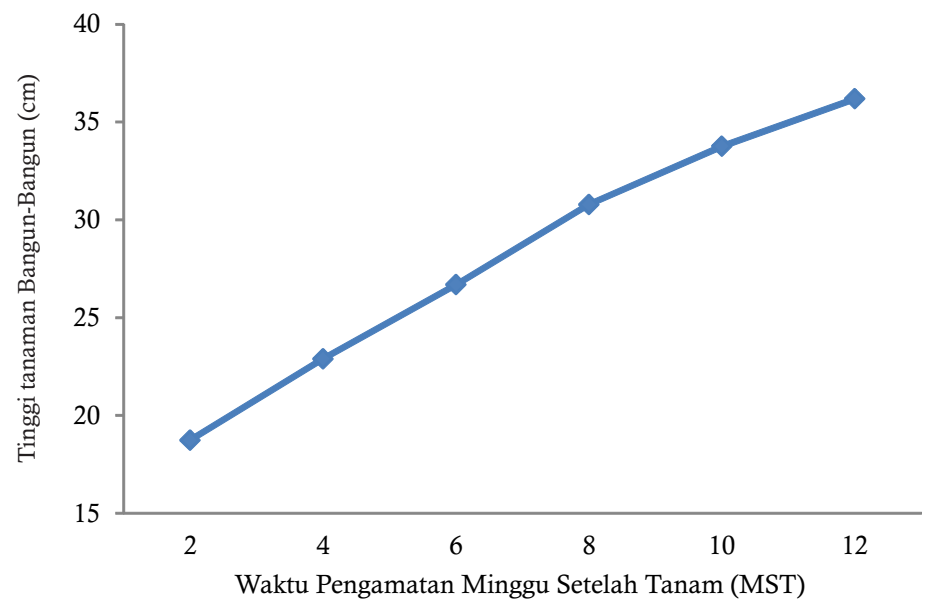

Gambar 3. Grafik tinggi tanaman bangun-bangun pada setiap waktu pengamatan.

daun akan berwarna kekuningan, menggulung dan terlihat pertumbuhannya kurang baik (Aziz, 2013). Intensitas cahaya dapat mempengaruhi aktivitas pertumbuhan, perubahan morfologi karakter fisiologis, aktivitas metabolit primer dan sekunder (Rahardjo, 2013).

Curah hujan pada saat penanaman termasuk musim kering dengan jumlah curah hujan berkisar $35 \mathrm{~mm}$ sehingga pada saat penanaman dibutuhkan air yang cukup banyak untuk penyiraman. Curah hujan meningkat pada saat satu bulan setelah tanam hingga menjelang panen (Gambar 4). Kondisi tersebut menunjukkan bahwa pertumbuhan tanaman bangun-bangun cukup optimal dilihat dari jumlah cabang, lebar tajuk dan jumlah daun tanaman bangun-bangun. Pada pengamatan 12 MST tanaman bangun-bangun memiliki 4 6 cabang dengan kisaran jumlah daun \pm 56 daun dan lebar tajuk sekitar $56,80 \mathrm{~cm}$. Jumlah daun tanaman bangun-bangun tersebut berhubungan dengan tingkat klorofil tanaman dalam proses fotosintesis. Semakin banyak klorofil yang menangkap cahaya sebagai bahan energi kimia untuk menghasilkan

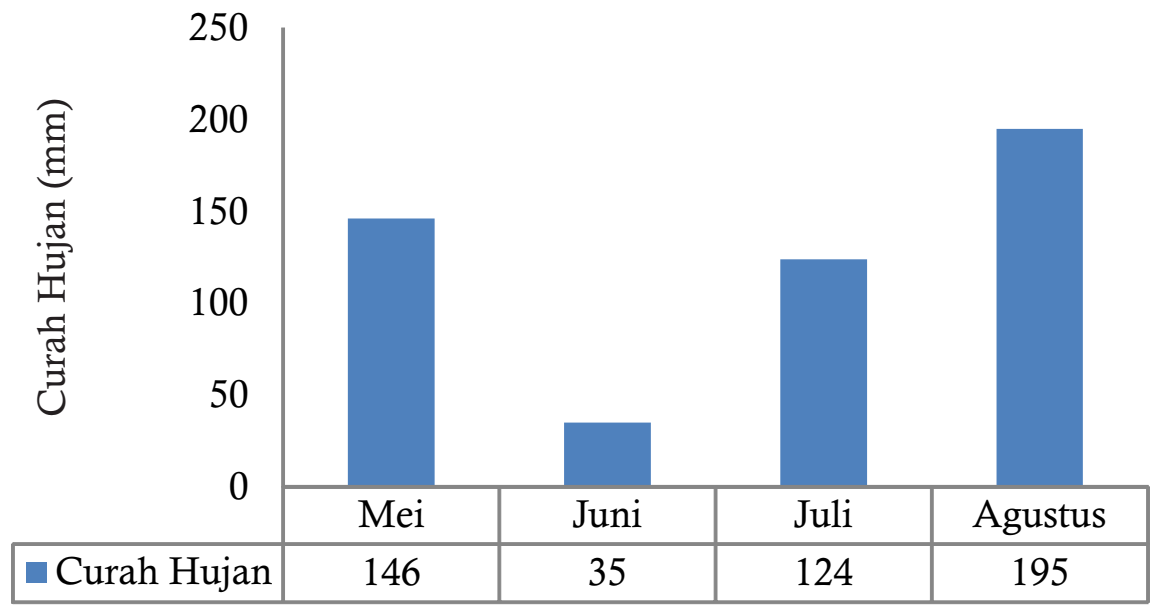

Gambar 4. Curah hujan pada lokasi penanaman bangun-bangun. 
karbohidrat dalam proses fotosintesis (Djukri \& Purwoko, 2013). Protein yang ada pada tanaman bangun-bangun yang ditanam di gawangan TBM karet menghasilkan sebanyak $15,44 \%$. Kandungan protein ini sesuai dengan penelitian Sajimin et al. (2011) yaitu sebanyak $11,44-15,38 \%$ protein kasar terdapat pada tanaman bangun-bangun. Dari hasil pengamatan variabel agronomi maka tanaman bangun-bangun dapat dibudidayakan dengan baik di gawangan TBM karet.

Hasil perhitungan bobot basah dan bobot kering dari hasil panen tanaman bangunbangun umur 12 MST setelah tanam adalah $8.756,92 \mathrm{~kg} / \mathrm{ha}$ dan $2.953,53 \mathrm{~kg} / \mathrm{ha}$. Dari hasil perhitungan tersebut diperoleh kadar air tanaman bangun-bangun sebesar $66,27 \%$. Hal ini menandakan bahwa tanaman bangunbangun memiliki kandungan air yang cukup tinggi. Tanaman bangun-bangun merupakan tanaman sukulen yang mampu menyimpan air dalam jaringan (Saraswathy et al., 2011). Biomassa yang dihasilkan dari tanaman bangun-bangun di gawangan karet seluas 1 ha adalah $8.860,50 \mathrm{~kg}$ sehingga dapat diasumsikan bahwa tanaman bangun-bangun dapat menyimpan karbon sebanyak 1.926,19 $\mathrm{kg} / \mathrm{ha}$. Jumlah karbon yang disimpan tanaman bangun-bangun lebih sedikit bila dibandingkan dengan tanaman cover crop lainnya karena jumlah daun, lebar tajuk dan jumlah cabang yang dihasilkan sedikit.

\section{Pengaruh Tanaman Bangun-bangun di Gawangan Karet Terhadap Penyakit JAP}

Hasil penelitian menunjukkan bahwa adanya penurunan intensitas serangan JAP di areal yang ditanami bangun-bangun (Gambar 5), meskipun secara statistik (uji $\mathrm{T}$ ) belum menunjukkan perbedaan yang nyata. Persentase penghambatan JAP masih rendah yakni sebesar 23,53\%, hal ini disebabkan karena waktu penanaman relatif singkat (3 bulan) untuk bahan pengujian di laboratorium.

Hasil skrining fitokimia pada akar bangunbangun menunjukkan hasil positif pada senyawa flavanoid, glikosida dan saponin (Dalimunthe et al., 2016). Saponin digunakan sebagai antimikroba dan mekanisme kerjanya adalah menurunkan tegangan permukaan sehingga mengakibatkan naiknya permeabilitas atau kebocoran sel dan mengakibatkan senyawa interseluler akan keluar (Bilalis et al., 2012). Hasil penelitian Manurung et al. (2014) menyimpulkan bahwa ekstrak tanaman bangun-bangun mampu menghambat perkembangan JAP di areal

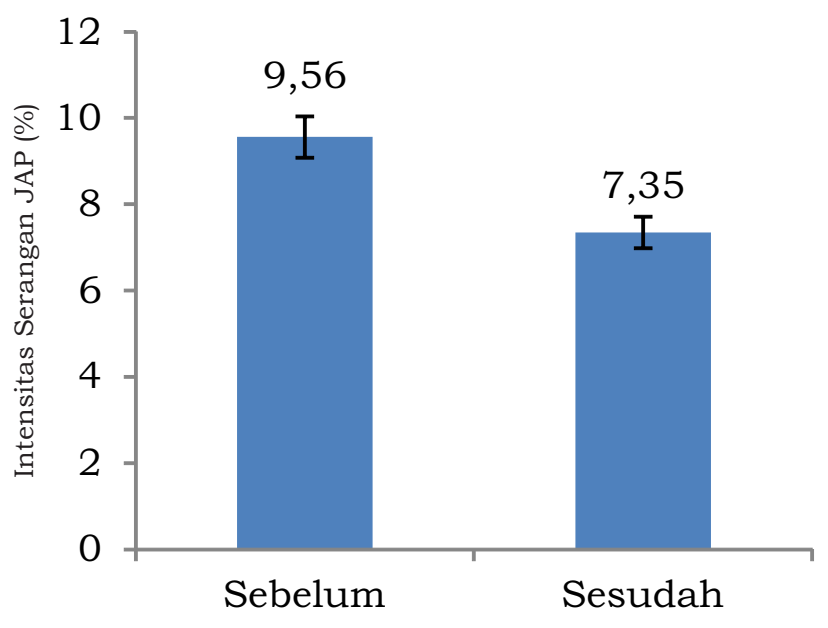

Gambar 5. Intensitas serangan JAP (kiri) di gawangan TBM karet selama tiga bulan penanaman bangun-bangun. 
tanpa olah tanah (TOT) sebesar $87,47 \%$ dengan intensitas serangan $1,67 \%$ berbeda nyata dengan kontrol sebesar $13,33 \%$ pada pengamatan 3 BSA (bulan setelah aplikasi). Hasil penelitian Wahyudi (2016) juga menunjukkan bahwa kombinasi antara menanam langsung tanaman bangun-bangun jarak $1 \mathrm{~m}$ dari tanaman karet dan aplikasi ekstrak bangun-bangun dapat mengendalikan penyakit JAP $>90 \%$ (pada tingkat skala serangan 1 dan 2) di TBM karet.

\section{Sifat Fisik dan Kimia Tanah Sebelum dan Sesudah Penanaman Bangun-Bangun}

Hasil pengukuran analisis tanah menunjukkan sifat fisik dan kimia tanah sebelum dan sesudah penanaman bangunbangun di areal gawangan TBM karet tertera pada Tabel 1. Sifat fisik tanah menunjukkan adanya peningkatan fraksi liat dan debu. Meskipun fraksi pasir mengalami penurunan sesudah penanaman bangun-bangun, namun masih menunjukkan kandungan fraksi pasir yang masih tergolong relatif tinggi. Umumnya kandungan fraksi tanah pada lahan tanaman karet dengan faktor pembatas ringan memiliki kisaran tekstur tanah pasir 20-50\%, debu 20$50 \%$, dan liat $10-40 \%$ (Istianto \& Sembiring, 2014).

Ditinjau dari sifat kimia tanah, sebelum penanaman bangun-bangun, kondisi tanah memiliki tingkat kesuburan yang rendah dan tingkat kemasaman yang tinggi. $\mathrm{pH}$ rendah mengganggu serapan unsur hara dan pertumbuhan tanaman melalui ketersediaan unsur hara dan unsur yang bersifat racun bagi tanaman. Selain unsur hara yang rendah, KTK tanah juga rendah yang menyebabkan nilai kation-kation yang dipertukarkan rendah.

Perlakuan tanaman bangun-bangun di gawangan TBM karet meningkatkan kandungan unsur hara $\mathrm{P}_{2} \mathrm{O}_{5}, \mathrm{~K}_{2} \mathrm{O}$, serta kationkation yang dipertukarkan. Pada penelitian

Tabel 1. Hasil analisa fisik dan kimia tanah di gawangan.

\begin{tabular}{|c|c|c|}
\hline Parameter & Sebelum penanaman & Sesudah penanaman \\
\hline Fraksi Pasir (\%) & 68 & 58 \\
\hline Fraksi Debu (\%) & 8 & 16 \\
\hline Fraksi Liat (\%) & 24 & 32 \\
\hline $\mathrm{pH}$ & 4.9 & 5.1 \\
\hline $\mathrm{C}(\%)$ & 0.85 & 0.92 \\
\hline $\mathrm{N}(\%)$ & 0.14 & 0.16 \\
\hline $\mathrm{P}_{2} \mathrm{O}_{5}$ Bray 2 (ppm) & 5.35 & 5.57 \\
\hline $\mathrm{K}_{2} \mathrm{O}(\mathrm{mg} / 100 \mathrm{~g})$ & 0.12 & 1.19 \\
\hline $\mathrm{Ca}-\mathrm{Exc}(\mathrm{me})$ & 0.68 & 3.75 \\
\hline $\mathrm{Na}-\operatorname{Exc}(\mathrm{me})$ & 0.05 & 0.26 \\
\hline $\mathrm{Mg}-\operatorname{Exc}(\mathrm{me})$ & 0.43 & 0.82 \\
\hline KTK (me) & 7.31 & 8.57 \\
\hline Al-dd & 0.03 & 0.04 \\
\hline
\end{tabular}


ini, sesudah penanaman bangun-bangun, kation yang dipertukarkan seperti $\mathrm{Ca}, \mathrm{Na}$, dan $\mathrm{Mg}$ meningkat dikarenakan KTK tanah mengalami peningkatan menjadi 8,57. Kapasitas tukar kation memberi gambaran tentang kemampuan tanah memegang hara untuk dapat dipertukarkan. Tanah dengan KTK yang tinggi mampu menyerap dan menyediakan unsur hara lebih baik dari pada tanah dengan KTK rendah. Hal ini disebabkan unsur hara terdapat dalam bentuk kompleks jerapan koloid sehingga unsur hara tersebut tidak mudah hilang tercuci oleh air (Hardjowigeno, 1987). Pada tanah yang mempunyai KTK rendah, bahan organik (Corganik) menjadi sangat penting dalam meningkatkan nilai KTK tanah. Hal ini diperkuat oleh pernyataan Havlin, et al. (2005) bahwa tinggi rendahnya KTK tanah sangat terkait dengan kandungan bahan organik di dalam tanah serta $\mathrm{pH}$ tanah.

\section{Kesimpulan dan Saran}

Berdasarkan hasil penelitian dapat disimpulkan bahwa tanaman bangun-bangun dapat tumbuh dengan baik di gawangan tanaman karet pada TBM 3 ditinjau dari karakter agronomi yang diamati. Manfaat dari penanaman bangun-bangun ini dapat menurunkan tingkat serangan jamur akar putih (JAP) sebesar 23,53\%. Disamping juga dapat meningkatkan kesuburan tanah melalui kandungan protein yang diperoleh cukup tinggi dalam kaitannya ketersediaan hara nitrogen dalam tanah. Penelitian lebih lanjut perlu dilakukan penanaman pada gawangan tanaman karet menghasilkan (TM) agar diperoleh perbandingan budidaya tanaman bangun-bangun dan manfaatnya sebagai pengendali JAP dan kesuburan tanah.

\section{Ucapan Terima Kasih}

Ucapan terima kasih disampaikan kepada DIPA Badan Penelitian dan Pengembangan
Pertanian yang telah membiayai penelitian ini melalui Program Kerjasama Kemitraan Penelitian dan Pengembangan Pertanian Nasional (KKP3N) periode tahun 2015.

\section{Daftar Pustaka}

Ansari, M., Anurag, A., Fatima, Z., \& Hameed, S. (2013). Natural phenolic compounds: a potential antifungal agent. In A. Mendez Vilas (Ed.), Microbial pathogens and strategies for combating them: science, technology and education (Vol. 2, pp. 11891195). Badajoz, Spain: Formatex research center.

Aziz, S. A. (2013). Prosedur operasional baku budidaya bangun-bangun. Plectranthus amboinicus. Retrieved from https://www. researchgate.net/

Basuki, \& Sinulingga, W. (1996). Penyakit akar putih pada tanaman karet. Gejala penyakit, pengendalian hayati, dan saran-saran pengendalian penyakit. Warta Pusat Penelitian Karet, 15(2), 96-104.

Bilalis, D., Kakabouki, I., Karkanis, A., Travlos, I., Triantafyllidis, V., \& Dimitra, H. (2012). Seed and saponin production of organic quinoa (Chenopodium quinoa Willd.) for different tillage and fertilization. Notulae Botanicae Horti Agrobotanici Cluj$N$ a p o c a , 40 ( 1 ), 42 - 46 . doi:10.15835/nbha4017400

Dalimunthe, C. I., Sembiring, Y. R. V., Andriyanto, M., Siregar, T. H., Darwis, H. S., \& Barus, D. A. (2016). Identifikasi dan uji metabolit sekunder bangun-bangun (Coleus amboinicus) terhadap penyakit jamur akar putih (Rigidoporus microporus) di laboratorium. Jurnal Penelitian Karet, 34(2), 189-200. doi:10.22302/ ppk.jpk.v34i2.295 
Damanik, R., Wahlqvist, M. L., \& Wattanapenpaiboon, N. (2006). Lactagogue effects of Torbangun, a Bataknese traditional cuisine. Asia Pacific Journal of Clinical Nutrition, 15(2), 267-274.

Djukri, I., \& Purwoko, B. S. (2003). Pengaruh naungan paranet terhadap sifat toleransi tanaman talas (Colocasia esculenta (L) Schott). Ilmu Pertanian, 10(2003), 17-25.

Ekawati, R. (2013). Produksi pucuk dan kadar metabolit bangun-bangun (Plectrancthus amboinicus (Lour.) Spreng) dengan pemupukan organik dan pemangkasan. (Thesis), Institut Pertanian Bogor, Bogor.

Fairuzah, Z., Dalimunthe, C. I., Karyudi, K., Suryaman, S., \& Widhayati, W. E. (2014). Keefektifan beberapa fungi antagonis (Trichoderma SP) dalam biofungisida endohevea terhadap penyakit jamur akar putih (Rigidoporus microporus) di lapangan. Jurnal Penelitian Karet, 32(2), 122128. doi:10.22302/ppk.v32i2.158

Harjowigeno, S. (1987). Ilmu Tanah. Jakarta, Indonesia: Mediyatama Sarana Perkasa.

Havlin, J. L., Beaton, J. D., Tisdale, S. L., \& Nelson, W. L. (2005). Soil fertility and fertilizers: An introduction to nutrient management (Vol. 515). Saddle River, New Jersey: Prentice Hall.

Istianto, \& Sembiring, Y. R. V. (2014, 3-5 Juni). Kesesuaian lahan untuk usaha perkebunan karet. Tulisan disajikan pada Workshop Pengelolaan Bahan Tanam dan Tanaman Karet Belum Menghasilkan Melalui Penerapan Siklus PDCA, Medan.

Manurung, L., Lubis, L., Marheni, M., \& Dalimunthe, C. I. (2014). Pengujian Berbagai Jenis Bahan Aktif Terhadap Penyakit Jamur Akar Putih (JAP)(Rigidoporus microporus (Swartz: Fr.)) di Areal Tanpa Olah Tanah (TOT). Agroekoteknologi, 3(1), 168-178.

Mualim, L. (2012). Produksi dan kualitas kolesom dengan pemupukan organik dan inorganik. (Doktor Disertasi), Institut Pertanian Bogor, Bogor.
Rahardjo, M. (2013). Pengaruh stres air, intensitas cahaya, konsentrasi karbon dioksida dan salinitas terhadap parameter fisiologis dan morfologis tanaman jahe (Zingiber officinale Rosc). In Miftahudin \& Efiana (Eds.), Bunga rampai jahe (Zingiber officinale Rosc.): status teknologi hasil penelitian jahe (pp. 36-48). Bogor, Indonesia: Balai Penelitian Tanaman Obat dan Aromatik

Rahayu, S., Pawirosoemardjo, S., \& Sujatno. (2006, 28-29 November). Biological control of white root disease of hevea rubber using trichoderma based biofungicide triko sp plus. Tulisan disajikan pada International Workshop on White Root Disease of Hevea Rubber, Salatiga.

Sajimin, Purwantari, N. D., Sutedi, \& Oyo. (2011). Pengaruh interval potong terhadap produktivitas dan kualitas tanaman bangun-bangun (Coleus amboinicus L.) sebagai komoditas harapan pakan ternak. Jurnal Ilmu Ternak dan Veteriner, 16(4), 288293.

Saraswathy, A., Amala, K., \& Arunmozhi, D. (2011). Coleus vettiveroides KC Jacob; Botany and Pharmacognosy. Indian Journal of Traditional Knowledge, 10(4), 636-642.

Setyawan, B., \& Admojo, L. (2009, 4-6 Agustus). Identifikasi batang bawah karet yang potensial resisten terhadap jamur akar putih. Tulisan disajikan pada Prosiding Lokayarya Nasional Pemuliaan Tanaman Karet, Batam.

Siagian, N. (2005). Pemanfaatan kayu karet dan optimalisasi penggunaan lahan untuk mendukung peremajaan. Jurnal Penelitian Karet, 23(2), 26-51.

Situmorang, A., Suryaningtyas, H., \& Febbianti, T. (2006, 28-29 November). The control of white root disease using antagonistic plant on rubber plantation Tulisan disajikan pada Internasional Workshop on White Root Disease of Hevea Rubber, Salatiga. 
Valera, D., Rivas, R., Avila, J. L., Aubert, L., Alonso-Amelot, M., \& Usubillaga, A. (2003). The essential oil of Coleus a mboinicus Loureiro chemical composition and evaluation of insect antifeedant effects. Ciencia, 11(2), 113-118.
Wahyudi, A. (2016). Pengaruh tanaman bangunbangun dan ekstrak tanaman bangun-bangun (Coleus amboinicus) terhadap jamur akar putih (Rigidoporus microporus) pada tanaman karet belum menghasilkan. (Skripsi), Sekolah Tinggi Ilmu Pertanian, Medan. 